\title{
DECISIONS
}

\section{A 19-year-old woman with sickle cell disease and pain}

\author{
Richard Ward MBBS MSc, Ewurabena Simpson MD MPH, Madeleine Verhovsek MD
}

A 19-year-old woman with homozygous sickle cell disease presents to her family physician's office with acute generalized bone pain. She reports stress from school deadlines. She prefers to manage her pain at home if possible and not go to the emergency department. She has no comorbidities.

\section{Is this patient having pain from a vasoocclusive crisis?}

She reports the character of the pain as being typical for a vasoocclusive crisis ("pain crisis"). She does not have any localized pain that may otherwise suggest complications of sickle cell disease, such as joint osteonecrosis, leg ulceration or cholecystitis. ${ }^{1,2}$ Because the duration and severity of her pain is short and moderate, she hopes the pain can be controlled with outpatient treatment.

The patient has no worrying features ("red flags") such as respiratory symptoms, neurologic changes, fever, previous admission to an intensive care unit (ICU) or history of exchange transfusion. ${ }^{1}$ Other common triggers of vasoocclusive crisis are excluded (e.g., infection, weather changes, dehydration and menstruation).

A physical examination did not show other causes for the pain, signs of infection, hypoxia or respiratory disease. ${ }^{3}$ Although pulse oximetry is not available in the office, the lack of respiratory signs and symptoms, with no history of respiratory concerns, is reassuring. Particularly in children, splenic palpation should be performed to rule out sequestration. ${ }^{4}$

\section{What diagnoses should be ruled out before outpatient treatment for vasoocclusive crisis?}

Complications from sickle cell disease that require management beyond hydration and analgesia must be treated in hospital. Acute chest syndrome is a leading cause of mortality. It is characterized by respiratory symptoms, hypoxia and/or fever, with an infiltrate on chest radiography. ${ }^{5}$ Acute stroke, priapism, splenic sequestration and surgical abdomen all require referral to the emergency department. Patients with febrile illness (body temperature $>38.3^{\circ} \mathrm{C}$ ), particularly in children, should also be referred to the emergency department because of the increased risk of overwhelming postsplenectomy or hyposplenic infection. ${ }^{6}$ Medical conditions unrelated to sickle cell disease that may account for the clinical findings should also be considered in these patients.

\section{Are any investigations necessary?}

Tests to assess for alternative or coexisting acute diagnoses should be carefully selected based on the likely differential diagnoses and the patient's presenting symptoms, such as fever, respiratory symptoms, localized pain or palpable splenomegaly. The diagnosis of vasoocclusive crisis is clinical and cannot be made by specific investigation., ${ }^{2,3}$

The patient's complete blood cell count results should be interpreted in the context of her steady-state hemoglobin level; this is usually in the range of 60-90 g/L in patients with homozygous sickle cell disease. ${ }^{1}$ A reticulocyte count can help to determine whether marked anemia is due to accelerated hemolysis or bone marrow suppression (e.g., viral illness or marrow suppression by hydroxyurea). A $20 \%$ drop from the baseline hemoglobin level or a reticulocyte count less than 80 warrants closer monitoring of the hemoglobin level and anemia symptoms. ${ }^{1}$

\section{What advice should be offered to the patient to help manage pain at home?}

Management of vasoocclusive crisis is symptomatic, and the patient should be advised of the following: administration of rapid, sustained and effective analgesia, which is titrated to an objective pain score, along with hydration (Box 1). Supplemental oxygen has not been proven to be beneficial in the setting of normal blood oxygen level.

There is a paucity of trial data that supports any one particular analgesia regimen, but the pain literature and expert consensus support the use of multimodal analgesia., ${ }^{2,9}$ Acetaminophen and a nonsteriodal anti-inflammatory drug should be prescribed with an opiate, unless oth-
Competing interests:

None declared.

This article has been peer reviewed.

The clinical scenario is fictional.

Correspondence to: Richard Ward, richard.ward@uhn.ca

CMAJ 2016. DOI:10.1503 /cmaj.150512 
Box 1: Summary of recommendations on managing vasoocclusive pain crises from current clinical guidelines ${ }^{3,7,8}$

Vasoocclusive crises are the most common presentations to health care providers by patients with sickle cell disease. The clinician should:

- Ascertain whether the current pain is typical of previous vasoocclusive crises.

- Evaluate patient for worrying features ("red flags") on history and physical examination.

- Use the 3Ps of pain management: physical, psychological and pharmacologic. Treat pain with rapid, sustained and effective analgesia, titrated to an objective pain score, and encourage hydration and rest.

- Prescribe acetaminophen, a nonsteroidal anti-inflammatory and an opiate, if no contraindications are present.

- Consider the use of hydroxyurea to reduce the incidence of future pain episodes. tology referral for counselling about hydroxyurea and was given tips about stress management.

\section{References}

1. The consensus statement on the care of patients with sickle cell disease in Canada, 2015. Ottawa: Canadian Haemoglobinopathy Association; 2015. Available: http://canhaem.org/the-consensus -statement-on-the-care-of-patients-with-sickle-cell-disease-in -canada/ (accessed 2015 Dec. 28)

2. Field JJ, Knight-Perry JE, Debaun MR. Acute pain in children and adults with sickle cell disease: management in the absence of evidence-based guidelines. Curr Opin Hematol 2009;16:173-8.

3. Rees DC, Olujohungbe AD, Parker NE, et al. Guidelines for the management of the acute painful crisis in sickle cell disease. $\mathrm{Br}$ J Haematol 2003;120:744-52.

4. Lee A, Thomas P, Cupidore L, et al. Improved survival in homozygous sickle cell disease: lessons from a cohort study. BMJ 1995;311:1600-2.

5. Guideline on the management of acute chest syndrome in sickle cell disease. London: British Society for Haematology; 2015.

6. Rubin LG, Schaffner W. Care of the asplenic patient. $N$ Engl $J$ Med 2014;371:349-56.

erwise contraindicated. ${ }^{1-3,7}$ Patients will often have a preferred opiate that they have found, with experience, to be effective. This patient should be informed about the safe and effective use of analgesia, including initial frequent doses to control pain quickly. Provincial drug databases may provide useful information on prior opiate requirements. She should also be advised to drink maintenance fluids for the duration of the pain episode (e.g., 2.0-2.5 L/day for adults). Transfusions of red blood cells are not recommended for uncomplicated vasoocclusive crisis.

\section{What follow-up can be instituted to prevent future episodes?}

Randomized controlled trials and long-term follow-up studies have shown that hydroxyurea reduces the frequency of vasoocclusive crisis and other complications by up to $50 \% .^{10,11}$ Hydroxyurea is now recommended for most patients with sickle cell disease for primary or secondary prevention of organ damage. ${ }^{1}$ The patient should be followed, ideally using a shared care model with a primary care physician, by a specialist in sickle cell disease. Steps should be taken to modify the trigger of the vasoocclusive crisis with the aim of reducing future episodes (e.g., in this instance, psychological stress).

\section{Case revisited}

Because the patient had no worrying features on history or physical examination of a complicated vasoocclusive crisis, she was prescribed immediate-release hydromorphone in conjunction with acetaminophen and ibuprofen, and was allowed to go home. An opiate contract was put in place. She was excused from school for the rest of the week. She rested at home, kept warm and drank adequate fluids. Her pain resolved, and she was seen in follow-up the next week. She agreed to a hemareport, 2014. Bethesda (MD): National Heart, Lung and Blood Institute; 2014

8. Dunlop RJ, Bennett KC. Pain management for sickle cell disease. Cochrane Database Syst Rev 2006; (2):CD003350.

9. Dampier CD, Smith WR, Kim H-Y, et al. Opioid patient controlled analgesia use during the initial experience with the ized sickle cell patients with painful episodes. Am J Hematol 2011;86:E70-3.

10. Ballas SK, Bauserman RL, McCarthy WF, et al. Hydroxyurea and acute painful crises in sickle cell anemia: effects on hospital length of stay and opioid utilization during hospitalization, outpatient acute care contacts, and at home. J Pain Symptom Manage 2010; 40:870-82.

11. Steinberg MH, McCarthy WF, Castro O, et al. The risks and benefits of long-term use of hydroxyurea in sickle cell anemia: a 17.5 year follow-up. Am J Hematol 2010;85:403-8.

Affiliations: Division of Medical Oncology and Hematology (Ward), University Health Network; and Division of Hematology (Ward), University of Toronto, Toronto General Hospital, Toronto, Ont.; Division of Hematology/Oncology (Simpson), Children's Hospital of Eastern Ontario; and Faculty of Medicine (Simpson), University of Ottawa, Children's Hospital of Eastern Ontario, Ottawa, Ont.; Division of Hematology and Thromboembolism (Verhovsek), McMaster University, St. Joseph's Healthcare, Hamilton, Ont.

Contributors: All of the authors contributed substantially to the conception of the article, drafted the work, approved the final version to be published and agreed to act as guarantors of the work. dence-based approaches to common presentations in primary care. The articles address key decisions that a clinician may encounter during initial assessment. The information presented can usually be covered in a typical primary care appointment. Articles should be no longer than 650 words, may include one box, figure or table and should begin with a very brief description (75 words or less) of the clinical situation. The decisions addressed should be presented in the form of questions. A box providing helpful resources for the patient or physician is encouraged.
7. Evidence-based management of sickle cell disease: expert panel IMPROVE PCA trial: a phase III analgesic trial for hospital-

Decisions is a series that focuses on practical evi- 